\author{
JELENA AVRAMOVIĆ ${ }^{1}$ \\ ANA VELIČKOVIĆ ${ }^{2}$ \\ VLADA VELJKOVIĆ 3 \\ 1,2,3 University of Niš, \\ Faculty of Technology in Leskovac \\ Iavramjelena@yahoo.com \\ 2anamarjan@yahoo.com \\ ${ }^{3}$ veljkovicvb@yahoo.com
}

\title{
CHALLENGES IN BIODIESEL INDUSTRY: SOCIO-ECONOMIC, OCCUPATIONAL HEALTH, AND POLICY ISSUES
}

\begin{abstract}
Faced with the problem of the depletion of fossil fuels, the concern about energy security, especially in the energy depended countries due to constant conflicts in the oil-exporting countries, as well as the climate change due to burning of fossil fuels, the society recognized biofuels as the solution to many of these problems. Namely, the growing biofuel sector could provide the possibility for the development of rural areas and creating job opportunities for the local population, contribute to the development of strong selfsufficient communities and reduce the emission of greenhouse gases due to the belief that the burning of biofuels was carbon neutral. However, over the years, some issues regarding biofuel production and use emerged, showing that it was not all "black and white", and that some side effects, such as the influence of biofuels on energy and food market, working conditions and workers' rights regarding occupational health, the inconsistency of biofuel policies, the land change, etc. should also be addressed to.
\end{abstract}

Key words: biodiesel production, workers' rights, working conditions, occupational health and safety.

\section{INTRODUCTION}

The society is facing the depletion of fossil fuels and severe climate change in the near future. The concern about world's fossil fuel reserves and the tendency of reducing the climate change related to greenhouse gas emissions have led to the conclusion that it will not be enough only to reduce the amount of fossil fuels used, but it is also necessary to change the used source of energy. Hence, renewable and sustainable energy sources have become the subject of many research projects. Over the past two decades, the use of biodiesel has been publicly recommended for many reasons, both practical and environmental. It is believed that the possibility of the production and the use of biodiesel will reduce the dependence on the imported oil, raise the security of the European energy supply, encourage the sustainable exploitation of natural sources, and reduce the emissions of greenhouse gases from transportation [1].

An extended biofuels sector challenges the sustainable development of rural economies associated with the issues of biofuels, food security, and food prices. The influence of the biomass energy programs is promising for the development of rural regions, where almost all feedstock, except municipal solid wastes, are located and can provide the non-agricultural income to many small farms. In many countries, rural economies and small farmers benefit from the local biofuel industries [2].

Despite their relative simplicity, several aspects of biodiesel production processes should be taken into consideration in order to ensure their productive, safe, and environmentally friendly running. Many large biodiesel production companies comply with the health and safety rules and regulations. Additionally, they constantly finance their worker's training concerning health and safety. On the other hand, smaller biodiesel producers struggle with financing and resources and usually do not meet the Occupational Safety and Health Administration workplace safety standards [3].

This paper deals with the socio-economic, occupational health and policy issues of biodiesel production and use.

\section{SOCIO-ECONOMIC ISSUES OF BIODIESEL PRODUCTION AND USE Energy security}

At the very beginning, biodiesel was presented as a "win-win" solution to energy and environmental problems, since it can be produced from oilseed crops that capture and store energy from the sun. The burning of biodiesel is considered carbon neutral because it will only release the amount of $\mathrm{CO}_{2}$ previously absorbed from the atmosphere by the plants for the process of photosynthesis. Theoretically, a clean renewable domestically grown liquid energy can reduce dependency on fossil fuels, preserve foreign exchange, make opportunities for new jobs and reduce net greenhouse gas emissions [4]. Many countries have reduced their dependence on fossil fuels and their usage of foreign oil with the use of locally produced biodiesel. Creation of a balanced energy policy and

This paper was partly presented at the international conference "Man and Working Environment", Faculty of Occupational Safety in Niš, December 2018, Niš. 
contribution to the development of a stronger selfsufficient community through the community-based biodiesel distribution program that brings economic, social, and environmental benefits to the community should be the mission of the biodiesel industry. The basic idea of the self-sufficient community is that local people and local products are engaged in the production process. Namely, local farmers are growing the feedstocks on their land, harvest and sell them to the local biodiesel production facility that produces and distributes the biodiesel to the end consumer. In that way, the money remains in the community, ensuring the local energy security and reducing the negative influence on the local environment [5]. However, though biodiesel produced in the community contributes to energy security, it should not be produced at any cost, especially if an area is not convenient for the cultivation of feedstock for its production. In that case, transportation of these crops to the production place causes the emission of greenhouse gases and imposes the additional costs for the society.

\section{Food markets: fuel vs food controversy}

In the agricultural market, there is a competition between the biodiesel industry and the food and feed manufacturers for the same commodity [6]. The growing request for bioenergy influences agricultural systems and food prices. Agriculturists choose to cultivate certain crops based on their prices. When profits from biomass cultivation exceed profits from food production, they will shift from food towards energy crop cultivation, until agricultural goods prices increase, which consequently increases food prices [7].

However, taking into account the greater size of the energy market in comparison to the food market, a small change in energy request would significantly influence the request for food crops, which will enhance the price of biodiesel and affect food crops prices [6]. It is believed that the connection between food and energy prices through biofuel policies caused the food price crisis in 2006 [8].

The use of various edible oils (first generation feedstock) in the biodiesel production induced the food versus fuel controversy. Namely, for years some edible oils were widely used in biodiesel production due to their availability and low price. The crops cultivated for the use in human nutrition and edible oils were converted to fuel despite the hunger and famine in the world [9].

Although advocates of bioenergy suggest that competition between food and fuel could be avoided by growing energy crops on less fertile land, this has not yet been economically analyzed [7]. This controversy can be avoided using second-generation feedstocks, such as waste oils, non-edible oils from oilseed varieties having high oil content that are grown on less fertile land, or using co-products of, for example, industrial corn processing, such as corn germ, very reach in oil content $[10,11]$. Also, different waste animal fats, such as pork lard, beef tallow, chicken fat, and yellow and brown greases, fish oils, all by-products of the meat and fish processing industries, can be suitable feedstocks for biodiesel production [12].

Microalgae present third generation feedstock for biodiesel production and a very promising alternative to oily feedstock, since they give higher energy yield per square area in comparison to land crops, they do not compete with food supplies, require smaller area for cultivation, and can be cultivated on areas that are not suitable for cultivation of plants, so they do not threaten arable land $[13,14]$. Implementation of biofuel production can contribute to the development of rural areas and provide the non-agricultural income to many small farms since the majority of feedstocks for biodiesel production are planted in these areas.

\section{The possibility of additional employment}

An expanded biofuels sector can benefit to the development of local economies of many rural agricultural areas and offer the possibility of creating additional employment not only in the plant construction period but in the refineries that require expertise in chemistry, engineering and management, as well [2]. In this way, young people would be motivated to stay, i.e. live and work in these communities [15]. Nevertheless, there is a shortage of evidence on the significant, long-term positive job impacts of the increased biofuel production in rural areas [15]. In addition, most of the working positions in the biodiesel production sector are only for low qualified seasonal field workers, often migrants that are especially vulnerable facing health risks, first of all, due to the inadequate use of agrochemicals. Better working conditions and worker rights should be a part of the standards for biodiesel production and trade [16].

\section{OCCUPATIONAL HEALTH ISSUES IN BIODIESEL INDUSTRY}

In biodiesel production plants, safety should be the priority. Biodiesel is commonly produced from different biological renewable recourses by the transesterification (alcoholysis) of triacylglycerols (TAGs) or the esterification of free fatty acids (FFAs), with an excess of methanol or ethanol, in the presence of an acid, base or enzyme catalyst although noncatalytic processes are also used [10]. Hence, accidents involving chemicals and/or large volumes of vegetable oil, biodiesel, or by-products can cause injury, loss of life, property damage, or environmental pollution [17].

As nonflammable and biodegradable, biodiesel itself presents a relatively safe product while the chemicals used for its production present a potential health and safety risk. Since $\mathrm{KOH}$ or $\mathrm{NaOH}$ used as a homogeneous catalyst may cause severe skin damage and eye irritation, their storage and usage need special attention. Methanol and ethanol are commonly used in the production of biodiesel. Methanol is most often used because of its physicochemical properties, low 
cost, mild reaction conditions, fast reaction time, and easy phase separation [18]. The main risks of its use are related to the possibilities of fire and explosion. It was observed that most of the accidents involving methanol have occurred in so-called "backyard utilities" (total biodiesel capacity lower than about 30000 tons/year) during batch operations or during maintenance activities [19]. The main problem in this small-scale biodiesel production plants is the small number of employees. The lack of financial support disables the owners to invest in safety management and workers' training. The workers are often unaware of the risk they are exposed to, especially if there are no visible or not at all signs of danger present in the production plant, nor are secured with safety equipment [3, 15]. For example, most of the workers in small-scale biodiesel production plants in South Africa were not provided with basic personal protection equipment, such as protective gloves, an apron, eye protective goggles, and mouth/nose protective masks [3]. Workers wear dirty greasy working clothes, and the lack of mouth and nose protective masks caused breathing in toxic chemicals and dust. Also, a smell coming from used oil and other chemicals could be detected, affecting workers exposed during working hours. On the other hand, the number of accidents involving methanol in the large-scale biodiesel production plants with a capacity larger than 100000 tons/year is negligible because they comply with the Occupational Safety and Health Administration workplace safety standards.

Commercial biodiesel production is generally based on the homogeneous base-catalyzed transesterification. The obtained crude biodiesel needs a complex purification that includes several washing steps during which a huge amount of wastewater is generated [20, 21]. In addition, there are records of catastrophic accidents during the stage of by-product glycerol neutralization. Therefore, it is expected that heterogeneous catalysis will be a step closer to safer biodiesel production [19].

\section{BIODIESEL POLICY ISSUES}

In energy markets, liquid biofuels compete with petroleum-based fuels. While different policies like the mandated blending of biodiesel with petro-diesel, subsidies, and tax incentives can promote biodiesel use, limitations like the lack of vehicles that run on biodiesel blends, can discourage their use. Although the prices of biofuels and fossil fuels move together, the current technologies for biodiesel production make the price of biodiesel too high for it to compete with fossil fuels without the active government policies through subsidies and tax credits, the import tariffs and the designated goals [6].

The main driving force for governments' involvement in the renewable energy sector should be the improvement of overall social welfare. Energy security, supply, affordability, and sustainability, adaptation to and mitigation of climate change, and employment opportunities, first in rural regions, are the energy, environmental, and social reasons for the governments' involvement in the renewable energy sector. However, the government must implement policies with public support, thus ensuring the support for the re-election [22].

White et al. (2013) [22] explained the importance of policy consistency in the developing renewable energy sector. Governments' non-predictable policy presents the main obstacle that causes short- and the long-term problems for the renewable energy industry. If the state budgets are adopted annually, with no legally bonded decisions in the coming years, the consequential uncertainty is making difficult to increase capital for investments. Policy changes of great extent may suddenly occur within the following year due to the increased lobbying activity, rapidly making profitable businesses unprofitable and making future investments in the industrial development more difficult. The industry must make an effort to constantly be aware of the current situation, so it could influence in time the government's decision process to the greatest extent possible. The main request of the investors or those who support the development of renewable energy sector for is the implementation of predictable, longterm stable policies that minimize insecurity, and not necessarily subsidies [22].

Besides positive effects of growing biofuel sector, such as the poverty reduction in developing countries, the development of rural areas and creating job opportunities, as well as the social welfare of developed countries, there are many, socio-economic, environmental and health side effects, financial and non-financial, which present additional expenses for the society that should be taken into consideration when developing a biofuel policy [4,23].

\section{CONCLUSION}

Policy-driven investment in growing biodiesel sector was based on positive effects of biodiesel production and use would have on energy security, development of rural areas and reduction of unemployment, and climate change. However, growing biofuel sector imposed several very important interrelated issues that should be critically analyzed. First, increased demand for biodiesel requires large quantities of oilseed crops and therefore large arable areas for their planting, which is why land change must be done very carefully to ensure that no land used for food is used for growing crops for biodiesel production [24-26]. However, it seems that in the recent future, the policy-driven growing demand for biodiesel will most likely lead to an accelerated conversion of non-agricultural lands to crop production [6]. Even if the more agricultural area are available for growing crops, it is questionable whether the reduction of greenhouse gas emission gained by the use of biofuels justifies the increased nitrous oxide emissions from the fertilizer used in growing crops [20]. The impact of growing biofuel sector on food supplies and 
prices has raised great concern for the poor although it has been emphasized that biofuels do not have to inevitably negatively affect food since it can be produced on lower quality lands [2]. These concerns hopefully will be overcome by the growing orientation towards second- and third-generation biofuels, directly investing in the feedstocks that have the highest positive greenhouse gas balances with the lowest environmental and social costs [27]. Considering alleviated global warming as one of the objectives of biodiesel support policies, fuel efficiency, and forest conservation and restoration will be the more effective solution since more carbon would be sequestered over a 30 -year period by converting the cropland to forest [28]. Hence, at this moment, biofuel seems to be an expensive choice of reducing greenhouse gases considering all the costs invested in their development, including subsidies and tax reductions [16].

\section{REFERENCES}

[1] F. Neuwahl, A. Löschel, I. Mongelli, L. Delgado: "Employment impacts of EU biofuels policy: combining bottom-up technology information and sectoral market simulations in an input-output framework", Ecological Economics, Vol. 68, 2008, pp. 447-460.

[2] B.D. Solomon: "Biofuels and sustainability", Annals of the New York Academy of Sciences, Vol. 1185, 2010, pp. 119-134.

[3] S.C. Thaba, C. Mbohwa, A. Pradhan, Occupational health and safety in the biofuel industry: the case study of small scale biodiesel plants in Gauteng Province, South African, Proceedings of the World Congress on Engineering and Computer Science 2015 Vol II, WCECS 2015, October 21-23, 2015, San Francisco, USA

[4] K. Jaeger,T. M. Egelkrau: "Biofuel economics in a setting of multiple objectives and unintended consequences", Renewable and Sustainable Energy Reviews, Vol. 15, 2011, pp. 4320-4333.

[5] http://www.biodiesel.com/biodiesel/benefits/

[6] FAO: "The state of food and agriculture; Biofuels: prospects, risks and opportunities", Food and Agriculture Organization of the United Nations; 2008, Rome.

[7] D.J.A. Johansson, C. Azar: "A scenario based analysis of land competition between food and bioenergy production in the US", Climatic Change, Vol. 82, 2007, pp. 267-291.

[8] S. Nazlioglu, C. Erdem, U. Soytas: "Volatility spill over between oil and agricultural commodity markets", Energy Economics, Vol. 36, 2013, pp. 658-665.

[9] J. Kansedo, K.T. Lee: "Process optimization and kinetic study for biodiesel production from non-edible sea mango (Cerbera odollam) oil using response surface methodology", Chemical Engineering Journal, Vol. 214, 2013, pp. 157-164.

[10] V.B. Veljković, M.O. Biberdžić, I.B. Banković-Ilić, I.G. Djalović, M.B. Tasić, Z.B. Nježić, O.S. Stamenković: "Biodiesel production from corn oil: A review", Renewable and Sustainable Energy Review, Vol. 91, 2018, pp. 531-548.
[11] Z. Nježić, I. Banković-Ilić, O. Stamenković, V. Veljković: "Environmental aspects of the production and use of corn oil biodiesel, Proceedings of the $18^{\text {th }}$ International Conference "Man and Working Environment: 50 Years of Higher Education, Science and Research in Occupational Safety Engineering," pp. 83-88, December 6 and 7, 2018, Niš, Serbia.

[12] I.J. Stojković, I.B. Banković-Ilić, A.V. Veličković, J.M. Avramović, O.S. Stamenković, D.S. Povrenović, V.B. Veljković: "Waste lard methanolysis catalyzed by $\mathrm{KOH}$ at moderate temperatures", Chemical Engineering and Technology, Vol. 39, 2016, pp. 741-750.

[13] B.R. Danilović, J.M. Avramović, J.T. Ćirić, D.S. Savić, V.B. Veljković: "Production of biodiesel from microalgae", Hemijska industrija, Vol. 68, 2014, pp. 213-232.

[14] A.F. Clarens, E.P. Resurreccion, M.A. White, L.M. Colosi: "Environmental life cycle comparison of algae to other bioenergy feedstocks", Environmental Science \& Technology, Vol. 44, 2010, pp. 1813-1819.

[15] Institute of Medicine: "The nexus of biofuels, climate change, and human health: Workshop summary", The National Academies Press, 2014, Washington, DC.

[16] Y. Greiler: "Biofuels, opportunity or threat to the poor?", Natural Resources and Environment Division, Swiss Agency for Development and Cooperation SDC, 2007.

[17] Biodiesel safety and best management practices for small-scale noncommercial use and production, available

https://www.canr.msu.edu/uploads/files/Fuels/Biodiesel $\% 20$ Safety $\% 20$ BMPs $\% 20$ for $\% 20$ Small $\% 20$ Scale $\% 20 U$ se\%20Production.pdf

[18] J.M. Avramović, A.V. Veličković, O.S. Stamenković, K.M. Rajković, P.S. Milić, V.B. Veljković: "Optimization of sunflower oil ethanolysis catalyzed by calcium oxide: RSM versus ANN-GA", Energy Conversion and Management, Vol. 105, 2015, pp. 1149-1156.

[19] E. Salzano, M. Di Serio, E. Santacesaria: "Emerging risks in the biodiesel production by transesterification of virgin and renewable oils", Energy Fuels, Vol. 24, 2010, pp. 6103-6109.

[20] I.J. Stojković, O.S. Stamenković, D.S. Povrenović, V.B. Veljković: "Purification technologies for crude biodiesel obtained by alkali-catalyzed transesterification", Renewable and Sustainable Energy Reviews, Vol. 32, 2014, pp. 1-15.

[21] V.B. Veljković, O.S. Stamenković, M.B. Tasić: „The wastewater treatment in the biodiesel production with alkali-catalyzed transesterification", Renewable and Sustainable Energy Reviews, Vol. 32, 2014, pp. 40-60.

[22] W. White, A. Lunnan, E. Nybakk, B. Kulisic: "The role of governments in renewable energy: The importance of policy consistency", Biomass and Bioenergy, Vol. 57, 2013, pp. 97-105.

[23] K. Janda, L. Kristoufek, D. Zilberman: "Modeling the environmental and socioeconomic impacts of biofuels", IES Working Paper 33/2011. IES FSV, Institute of Economic Studies, Faculty of Social Sciences Charles University, 2011, Prague

[24] C.C. Tsao, J.E. Campbell, M. Mena-Carrasco, S.N Spak, G.R. Carmichael, Y. Chen: "Biofuels that cause land-use change may have much larger non - GHG air quality emissions than fossil fuels", Environmental Science \& Technology, Vol. 46, 2012, 10835-10841 
[25] J.H. Ng, H.K. Ng, S. Gan:'Recent trends in policies, socioeconomy and future directions of the biodiesel industry", Clean Technologies and Environmental Policy, Vol. 12, 2010, pp. 213-238.

[26] R. Righelato, D. V. Spracklen: "Carbon mitigation by biofuels or by saving and restoring forests?", Science, Vol. 317, 2007, pp. 902-906.

[27] L. Ruth: "Bio or bust? The economic and ecological cost of biofuels", EMBO Reports, Vol. 9, 2008, pp. 130-133.

[28] S.B. Živković, M.V. Veljković, I.B. Banković-Ilić, I.M. Krstić, S.S. Konstantinović, S.B. Ilić, J.M. Avramović, O.S. Stamenković, V.B. Veljković: "Technological, technical, economic, environmental, social, human health risk, toxicological and policy considerations of biodiesel production and use", Renewable and Sustainable Energy Reviews, Vol. 79, 2017, pp. 222247.

\section{ACKNOWLEDGEMENTS}

This work has been funded by the Ministry of Education, Science and Technological Development of the Republic of Serbia, Serbia (Project III 45001).

\section{BIOGRAPHY of the first author}

Jelena Avramović was born in Leskovac, Serbia, in 1979. She received the diploma and the Ph.D. degree in Chemical Engineering from the University of Nis, Faculty of Technology, Leskovac. Her main research

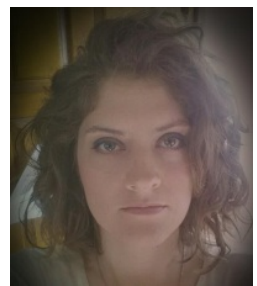
areas are Chemical Engineering and Bioenergy including biodiesel production and catalysis. She is currently with the Faculty of Technology in Leskovac, where she is working as a Senior Research Associate.

\title{
IZAZOVI ZA INDUSTRIJU BIODIZELA: SOCIOLOŠKO EKONOMSKA, PROFESIONALNO ZDRAVSTVENA I POLITIČKA PITANJA
}

\author{
Jelena Avramović, Ana Veličković, Vlada Veljković
}

\begin{abstract}
Rezime: Suočen sa problemom iscrpljivanja rezervi fosilnih goriva, zabrinutošću zbog energetske sigurnosti, naročito energetski zavisnih zemalja usled stalnih sukoba u zemljama koje izvoze naftu, kao i zbog klimatskih promena usled sagorevanja fosilnih goriva, svet je prepoznao biogoriva kao rešenje za mnoge probleme. Naime, smatra se da razvoj sektora biogoriva pruža mogućnost za unapređenja ruralnih područja $i$ zapošljavanja lokalnog stanovništva, doprinosi razvoju jakih nezavisnih zajednica i da može dovesti do smanjene emisije gasova staklene bašte usled verovanja da je sagorevanje biogoriva neutralno u pogledu količine oslobođenog ugljendioksida. Međutim, tokom godina pokazalo se da nije sve "crno-belo" i da treba skrenuti pažnju na neka pitanja $i$ neželjenie efekte u vezi sa proizvodnjom i primenom biogoriva, kao što je uticaj biogoriva na tržište hrane, uslove rada i prava radnika, zatim nedoslednost u politici biogoriva, izmena namene zemljišta itd.
\end{abstract}

Ključne reči: proizvodnja biodizela, prava radnika, uslovi rada, bezbednost i zdravlje na radu. 
